\title{
Niebezpieczny urok jednoznaczności - Paweł Smoleński Wnuki Jozuego (dydaktyka ostrzegawcza)
}

\author{
The treacherous charm of the unambiguous - \\ Paweł Smoleński’s Wnuki Jozuego [Joshua’s Grandchildren] \\ (cautionary didactics)
}

Summary: The author of the article stresses that what constitutes the purpose of humanistic education is showing the world from different perspectives and ambiguity as its inherent ingredient, which should be approached as both didactic and axiological challenge (especially in the light of concept of young people's civic education). In this context he proposes to have a glance at cultural microcosm (of today's Israel) described by Paweł Smoleński in his book published in 2019 entitled Wnuki Jozuego [Joshua's Grandchildren]. The Polish author of reportages shows in the said book how - based on the example of Jewish Israeli settlers in the West Bank — dealing with religious, ethnic, and cultural diversity and experiencing them on the daily basis, paves the way for radical views and, consequently, for unifying the past, present, and the future. Many among Smoleński's interlocutors/interviewees, however, touch upon the need for open dialogue, accepting otherness, and various outlooks on the most burning issues. Therefore, the story thus told may be treated as a warning against believing in only one righteous truth, as well as against the said belief's negative influence on the sphere of public exchange of thoughts.

Keywords: education, radicalism, anti-radicalism, reportage, diversity 
Światła, a nie światło. Wierzenia i opinie, nie wiara i opinia.

$\mathrm{Amos} \mathrm{Oz}^{1}$

Przywołane słowa najbardziej chyba znanego w Polsce izraelskiego prozaika wybrane zostały na motto tego artykułu, ponieważ podkreślają, jak wielką wartość w refleksji nad otaczającym nas światem ma akceptacja różnorodności. Dlatego zaznaczające się między ludźmi różnice, nawet gdy powodują trudności we wzajemnym komunikowaniu się i zrozumieniu, trzeba chronić przed wszelkimi próbami ich niwelowania, zacierania czy niszczenia. Zamach na różnorodność bowiem jest w gruncie rzeczy zamachem na podstawowe prawa człowie$\mathrm{ka}, \mathrm{w}$ tym prawo do postrzegania świata $\mathrm{z}$ różnych perspektyw oraz prawo do ich poznawania. Płaci się za to oczywiście odpowiednią cenę, a jest nią życie w świadomości, że rzeczywistość, w jakiej funkcjonujemy, naznaczona jest nieusuwalnym piętnem niejednoznaczności. Ma to jednak, mimo wszystko, istotny walor edukacyjny, który opisuje Amos Oz:

Niektórzy dniem i nocą kładą nam do głowy, że „w jedności siła”. Nasza siła rzeczywiście tkwi w zjednoczeniu wokół prawa do bycia różnymi. Różność nie jest przejściowym złem, lecz źródłem błogosławieństwa. Różnica zdań nie jest uciążliwą słabością, lecz życiodajnym klimatem dla wzrostu kreatywności. Różnimy się między sobą nie dlatego, że niektórzy $\mathrm{z}$ nas jeszcze nie dostrzegają światła, ale dlatego, że na świecie jest wiele świateł, nie jedno. Wierzenia i opinie, a nie wiara i opinia²

Komentarz ten, pozwalający lepiej zrozumieć kontekst macierzysty sentencji użytej w roli motta, dobrze ilustruje również dylematy, przed jakimi staje dziś szkolna edukacja humanistyczna. Czy przybliżać świat i człowieka z jednej, etnocentrycznej, polonocentrycznej perspektywy, a więc (odwołując się do metaforyki zaproponowanej przez Oza), czy należy w szkole rozświetlać naszą tradycję (głównie narodową) i współczesność jedną, ale za to bardzo wąską, mocną wiązką światła nadającą im w miarę spójny i jednoznaczny sens? Czy nie lepszym rozwiązaniem byłoby skorzystanie z oświetlenia punktowego, znacznie bardziej rozproszonego, o mniejszym natężeniu, ale wydobywającego z mroku przeszłości oraz teraźniejszości problemy i kwestie (również te uniwersalne, ogólnoludzkie, ponadnarodowe) w sposób delikatniejszy, pozwalający dostrzec ich rozmaite odcienie, a nawet kryjące się w ciemnościach tajemnice i nierozstrzygalności?

Szukając argumentów przemawiających za tym, by rozważyć edukacyjny potencjał tkwiący w drugiej możliwości, warto sięgnąć po teksty, które opisu-

\footnotetext{
${ }^{1}$ A. Oz: Do fanatyków. Trzy refleksje. Tłum. L. Kwiatkowski. Poznań 2018, s. 71.

2 Ibidem, s. 61.
} 
ją świat i ludzi zmuszonych każdego dnia zmagać się z doświadczeniem różnorodności - religijnej, etnicznej, językowej, politycznej, konstytuującym ich codzienną rzeczywistość, tożsamość (indywidualną oraz zbiorową), a także relacje z Innym. Taki właśnie świat znajdziemy w Izraelu opisywanym w książce Pawła Smoleńskiego, czyli we Wnukach Jozuego (wydanej w 2019 roku).

\section{Różnorodność „podejrzana”}

Lektura tej opowieści ma istotne implikacje dydaktyczne. Uświadamia, że podejmowanie refleksji nad różnorodnością jest dziś właściwie koniecznością. Od tego bowiem zależą konkretne postawy, a ich wachlarz może być bardzo szeroki - od fascynacji, otwartości, uznania, do nienawiści, wrogości czy fanatyzmu. Smoleński pokazuje, że taki namysł jest wyzwaniem etycznym i psychologicznym; z jednej bowiem strony może prowadzić do zaciekle bronionego przekonania o słuszności tylko jednej racji i jednej perspektywy postrzegania świata, a z drugiej - do akceptacji tego, że odmienne racje i odmienne perspektywy mogą naruszyć fundamenty czyjegoś światoodczuwania, a nawet doprowadzić do rozpadu tego, co wydawało się dotąd pewne, stabilne i niepodlegające zakwestionowaniu.

Smoleński, wrzucając czytelnika w środek izraelskiego mikrokosmosu, pokazuje, że różnorodność stanowi jego immanentną cechę. Można doświadczyć kulturowego zawrotu głowy, analizując wielość poglądów i postaw, które są reprezentatywne dla poszczególnych grup żydowskiego społeczeństwa. Na to nakłada się wewnętrzne zróżnicowanie cechujące Palestyńczyków, wśród których są zarówno zwolennicy dialogu z Izraelem, jak i zaciekli wrogowie tego państwa z islamskimi fundamentalistami z Hamasu na czele, oraz niezwykła różnorodność religijna, z reguły bardzo ekspansywnie okazywana. Gdzie zatem, jeśli nie w tym miejscu naszej planety, można przyjrzeć się z bliska szansom i zagrożeniom wynikającym z doświadczenia różnorodności świata?

Smoleńskiego fascynują przede wszystkim status i sposób myślenia osadników żydowskich zamieszkujących tzw. terytoria okupowane przez państwo Izrael i położone na Zachodnim Brzegu Jordanu, a więc na terenach teoretycznie podlegających władzy Autonomii Palestyńskiej. W tym kontekście pojawiają się nazwy dwóch krain geograficznych znanych nam z kart Pisma Świętego, czyli Judea i Samaria. Reportażysta próbuje zrozumieć, skąd się bierze tak wielkie przywiązanie żydowskich mieszkańców położonych tam osiedli do tej przestrzeni i dlaczego administracja izraelska szczególnie ich chroni, ryzykując zbrojne akcje odwetowe (także terrorystyczne) ze strony militarnych ugrupowań palestyńskich. 
Roszczenia mieszkańców żydowskich osiedli na Zachodnim Brzegu wyprowadzone są z bardzo jednoznacznej interpretacji tekstów religijnych i starożytnych świadectw historycznych. Smoleński wyraźnie to eksponuje, przywołując w swojej opowieści obszerne fragmenty biblijnych historii, na przykład dotyczących wojen, jakie prowadził Jozue, oraz liczne wyimki z kronik Józefa Flawiusza. Co więcej, te odniesienia są także nader licznie obecne w wypowiedziach ludzi, z którymi reportażysta rozmawia. Zarówno on, jak i czytelnik odnoszą wrażenie, że dla izraelskich osadników oraz ich zwolenników czas uległ niezwykłej kompresji — dawne opowieści o zmaganiach izraelskiego narodu walczącego o uznanie prawa do swego istnienia i tworzenia własnych struktur państwowych, mimo że dotyczą zamierzchłej przeszłości i zupełnie innego kontekstu kulturowego, politycznego, społecznego, religijnego, są traktowane tak, jakby miały miejsce co najwyżej kilka lat wcześniej, jakby między drugą dekadą XXI wieku a wydarzeniami sprzed tysięcy lat istniała oczywista, logiczna i bezpośrednia więź (co zresztą intencjonalnie wyrażono w tytule książki).

Autor Wnuków Jozuego dostrzega taki sposób doświadczania relacji między współczesnością a przeszłością na przykład w Hebronie:

Abraham szedt z miasta Ur w Mezopotamii do ziemi Kanaan. Bywat w Egipcie i w Beer Szewie. Ale osobliwie upodobat sobie Hebron [...]. To, co zanotowano w Biblii, o czym pisat Józef Flawiusz [...] oraz wszystko, co działo się w Hebronie później, przez całe wieki nieprzerwanej żydowskiej obecności w mieście, jest dla tutejszych osadników historia ledwie poprzedniego dnia. Oni - co najwyżej - tu powrócili. Ich serca nigdy z Hebronu nie wyjechaty.

${ }^{3}$ P. Smoleński: Wnuki Jozuego. Wołowiec 2019, s. 82-83. Takich biblijnych śladów poświadczających prawo żydowskich osadników do spornej ziemi i niejako sakralizujących ich roszczenie jest oczywiście znacznie więcej (Smoleński skrupulatnie je wymienia). W Hebronie patriarcha Abraham pochował swoją żonę Sarę. Z kolei w pobliżu Tekoi prorok Jeremiasz przepowiedział niewolę babilońską oraz zburzenie Świątyni, a następnie w tym samym miejscu zapowiadał zakończenie niewoli i odbudowę Świątyni. Stąd pochodził również prorok Amos, który wedle podań został w tym mieście pochowany. Osiedle Szilo znajduje się w miejscu, gdzie Jozue postawił Namiot Spotkania i umieścił w nim Arkę Przymierza, natomiast Bejt Cherion to miejsce związane ze starożytnymi powstaniami żydowskimi wymierzonymi przeciw hellenistycznemu imperium Seleucydów, a potem imperium rzymskiemu, a więc z wydarzeniami symbolicznymi i znaczącymi dla żydowskiej tożsamości, uzasadniającymi ich późniejsze roszczenia narodowowyzwoleńcze. Ibidem, s. 127-129 i 172. W kontekście zażartego konfliktu religijnego wokół Wzgórza Świątynnego w Jerozolimie trzeba też przypomnieć, że chodzi tu o górę Moria, na której Abraham miał ofiarować Bogu swojego syna Izaaka (a według muzułmanów, jego brata — Izmaela). Dziś znajduje się tam słynny meczet Al-Aksa i Kopuła Na Skale, a więc świątynie bardzo ważne dla świata islamu. Według żydów jednak, kiedy nadejdzie Mesjasz, zostanie tam wzniesiona Trzecia Świątynia (wcześniej stały tu Pierwsza i Druga Świątynia) — jest to więc i dla nich miejsce święte. 
Takich biblijnych śladów poświadczających prawo żydowskich osadników do spornej ziemi i niejako sakralizujących ich roszczenie jest oczywiście znacznie więcej. To zakorzenienie osadniczej świadomości w odległej przeszłości (poprzedzającej narodziny islamu), w uświęconej tradycji, w świętych autorytetach i w świętej księdze stanowi interesujące świadectwo pragnienia ujednoznacznienia rzeczywistości współczesnej. Osadnicy wyraźnie kontestują prawa innej zbiorowości (Palestyńczyków) do tychże miejsc, a wszelkich żydowskich krytyków ich sposobu postrzegania rzeczywistości traktują jako zdrajców żydowskiej tożsamości. Akceptacja i uznanie różnorodności w tej perspektywie oznaczają de facto co najwyżej warunkowe przyzwolenie na współobecność Innego, ale pod warunkiem, że nie będzie przekraczał starannie wyznaczonych granic poszczególnych enklaw (w tym przypadku osiedli, stref itp. $)^{4}$ ani tym bardziej nie będzie zgłaszał wobec nich pretensji czy roszczeń, z góry uznanych za nieuzasadnione, krzywdzące i wymierzone przeciw samemu Bogu.

Wyłania się z tego interesujący, także $\mathrm{z}$ edukacyjnego punktu widzenia, mechanizm kwestionowania różnorodności jako wartości pożądanej. Znosi on wieloperspektywiczność postrzegania świata, mitologizuje przeszłość, ujednoznacznia jej sens, proponuje wyrazistą aksjologię (oddzielając bezdyskusyjnie przyjaciół od wrogów), sakralizuje przestrzeń, uzasadnia poczucie moralnej wyższości oraz przekonanie o przynależności do wspólnoty wybranej i wyjątkowej, połączonej tajemniczymi, ale oczywistymi więziami z Absolutem. Ten układ elementów budziłby zapewne niepokój i zdziwienie, gdyby dotyczył tylko jednej, i to oddalonej od nas, wspólnoty. Powinien jednak tak naprawdę budzić strach, gdyż otwiera drogę radykalizmowi i myśleniu co najmniej autorytarnemu, a są to zjawiska, które, mimo odmiennego kontekstu, a także innych uwarunkowań niż izraelskie, stają się coraz częściej możliwe do zaobserwowania w Europie (także w Polsce). Tak skonstruowany model postrzegania świata w zasadzie nie podlega zakwestionowaniu. Nie pozwala się poddać publicznej debacie, gdyż wyklucza wszelką dyskusję wyrastającą przecież z rozmaitości potencjalnych stanowisk, które należałoby uznać w punkcie wyjścia za równorzędne i równoprawne 5 .

${ }^{4}$ Symbolicznym wyrazem troski o trwałość tychże granic jest mur oddzielający terytoria izraelskie od terenów administrowanych przez Palestyńczyków.

${ }^{5}$ Potwierdzenie tego sposobu myślenia Smoleński dostrzega na przykład na ogrodzeniu wokół Ofry: Na płocie otaczającym Ofrę pojawity się plakaty z cytatami z Księgi Rodzaju o tym, że cała tutejsza ziemia należy do ludu Izraela, bo tak zadecydowat Bóg. P. Smoleński: Wnuki Jozuego..., s. 190. 


\section{W stronę radykalizmu}

Perspektywa kategoryzowania świata wyprowadzona z doświadczenia różnicy oraz traktowania Innego jako obcego i wroga, w połączeniu z opisanym sposobem rozumienia przeszłości, a także jej związku ze współczesnością, prowadzi ku radykalizmowi. W przypadku Izraela radykalizm ten dostrzec można po obu skonfliktowanych stronach. Nie dotyczy on jedynie sfery idei i intelektualnych konstrukcji światopoglądowych, ale całkiem realnie ingeruje $\mathrm{w}$ życie codzienne całych społeczności. Nie jest on oczywiście przypisany jednej narodowości czy jednej religii, nie ma też związku z określonym wiekiem czy wykształceniem. Jego immanentną cechą jest przekonanie, że odmienna od mojej wspólnota religijna, etniczna, kulturowa dąży do unicestwienia mojej wspólnoty albo stanowi jej realne zagrożenie — dlatego jeśli istniejących różnic nie można przezwyciężyć, należy nad nimi zapanować. W tym celu trzeba osiągnąć pozycję dominującą (w sferze politycznej, militarnej, gospodarczej itp.), a jeśli się to nie uda, warto raz po raz sięgać po przemoc, by drugą stronę przestraszyć lub/i poniżyć, a w skrajnym przypadku zabić jej przedstawicieli ${ }^{6}$.

Cechy takiej mentalności reportażysta odnajduje na przykład w Meirze Etingerze, przywódcy radykalnej organizacji żydowskich osadników znanej jako Młodzież ze Wzniesień. Mimo młodego wieku (urodził się w 1991 roku) uznawany jest za ikonę tej grupy. Jego fanatyczne poglądy wymierzone są, co ciekawe, zarówno w podstawy państwa Izrael, jak i rzecz jasna, są jawnie wrogie wobec Arabów. Nic dziwnego zatem, że jego działalność spędza sen z powiek izraelskim służbom bezpieczeństwa, bardziej obawiającym się, jak pisze Smoleński, terroryzmu żydowskiego niż palestyńskiego7. Reportażysta podkreśla, że w parze z przekonaniem Etingera, że zna, niczym prorok, niepodziel$n a$, jedyna prawdę ${ }^{8}$, idą konkretne działania polegające na aktach wandalizmu,

${ }^{6}$ Interesujący obraz prezentujący nie tylko kumulację owych napięć, lecz także ich tragiczne skutki, zarówno po stronie izraelskiej, jak i palestyńskiej, przedstawia serial Nasi chłopcy (reż. Joseph Cedar, Tawfik Abu Wael) wyprodukowany przez HBO, który swoją premierę miał w 2019 roku. Nawiązuje on do wydarzeń z 2014 roku, czyli do zamordowania przez palestyńskich terrorystów trzech nastoletnich żydowskich osadników (Ejala Jifraha, Gilada Szara i Naftalego Fraenkela), a następnie do porwania i zamordowania przez trzech młodych ortodoksyjnych żydów palestyńskiego nastolatka Muhammada Abu Khdeira (co miało być aktem odwetu za zbrodnię popełnianą na Izraelczykach). Serialowa rekonstrukcja przebiegu zdarzeń ukazuje, do czego prowadzą religijne zaślepienie, nienawiść, żądza zemsty za wszelką cenę oraz zaciekła wrogość wobec odmienności etnicznej, kulturowej, językowej i religijnej. W tej filmowej historii warto też zwrócić uwagę, jak łatwo opowieść o popełnionych zbrodniach zawłaszczają fanatycy po obu stronach izraelsko-palestyńskiego konfliktu oraz wykorzystują symbolicznie do wzmacniania wzajemnej wrogości i eskalowania rzeczywistej przemocy.

${ }^{7}$ Wspomniany serial interesująco opowiada również o tym aspekcie.

${ }^{8}$ P. Smoleński: Wnuki Jozuego..., s. 174. 
nękaniu i zastraszaniu Palestyńczyków, izraelskich Arabów, chrześcijan, działaczy pokojowych izraelskiej lewicy, rabinów sprzeciwiających się konfliktowi, a także starcia z izraelskim wojskiem oraz policją ${ }^{9}$.

Radykalizm nie uznaje też sfery sacrum ani żadnego tabu. Na przykład aresztowani podejrzani w związku ze zbrodnią w Dumie, popełnioną na rocznym arabskim chłopcu i jego rodzicach, byli posądzeni także o wcześniejsze podpalenie kościoła Prymatu Świętego Piotra nad Jeziorem Tyberiadzkim i atak na kościół Zaśnięcia Marii Panny w Jerozolimie, a na podstawie całej książki Smoleńskiego można by sporządzić obszerne zestawienie okrutnych zbrodni i aktów przemocy, jakich dopuścili się żydowscy i palestyńscy radykałowie. Ich ofiarami były dzieci (w tym niemowlęta - jak dziewięciomiesięczna Szalhewet Pas zastrzelona w Awraham Awinu przez palestyńskiego snajpera 26 marca 2001 roku), modlący się Palestyńczycy (jak na przykład ofiary ataku Barucha Goldsteina w Grocie Patriarchów z 1994 roku), nastolatkowie (na przykład wagarowicze - Kobi i Josef, bestialsko zamordowani w 2001 roku w pobliżu Tekoi przez arabskich sprawców, lub arabski chłopiec, którego porwali i spalili trzej żydowscy napastnicy w lipcu 2014 roku $^{10}$ ) czy kobiety w widocznej ciąży (jak podczas ataku palestyńskiego nastolatka z Betlejem w 2016 roku na mieszkańców Tekoi). W tej przerażającej kronice kryminalnej zdumiewa, jak często sprawcami tychże czynów byli bardzo młodzi ludzie.

Wielu żydowskich rozmówców reportażysty zastrzega, że jest to zbrodnicza aktywność dość małych grup (przynamniej jeśli chodzi o radykałów izraelskich) i podlega ona powszechnej krytyce. Powiązanie radykalizmu z mniejszością wcale nie służy jednak bagatelizowaniu problemu; mocno niepokoi ono na przykład osoby zaangażowane w działalność obywatelską i na rzecz praw człowieka, jak również służby specjalne Izraela. Poszukując genezy radykalnych postaw, zwłaszcza wśród młodych, odnajdują je w ich najbliższym środowisku - w wychowaniu, edukacji w rodzinach, w szkołach i jesziwach, we wpływie rodziców, rabinów i nauczycieli, a nawet w cichym przyzwoleniu udzielanym przez władze ${ }^{11}$.

${ }^{9}$ Ważną przestrzenią prezentowania swoich przekonań przez Młodzież ze Wzniesień jest Internet. Na stronach im sprzyjających odnaleźć można było na przykład instrukcję dotyczącą tego, jak przygotować atak z użyciem bomby zapalającej i jak go przeprowadzić, by nikt nie ocalał. Także jednak i w tym przypadku radykalizm wyrażany werbalnie bardzo szybko przeobraził się w radykalizm urzeczywistniony: Dokładnie wedle tej internetowej instrukcji w styczniu 2015 roku w wiosce Duma spalono rodzinę Dawabsze. Na domu zostawiono napisy ,Zemsta” $i$, Niech żyje Mesjasz Król”' z wymalowana obok liter charakterystyczna korona i gwiazda Dawida. Roczny chłopiec, Ali Dawabsze, zginął na miejscu. Jego rodzice (poparzenia sięgały ponad dziewięćdziesięciu procent ciała) zmarli w izraelskich szpitalach. Ocalat tylko Ahmed, pierworodny syn Riham i Saida, cudem uratowany przez wujka. Ibidem, s. 180.

${ }_{10}$ Zob. przypis 6.

${ }^{11}$ Zob. P. Smoleński: Wnuki Jozuego..., s. 165. 
Życie i formowanie własnej tożsamości wśród ludzi egzystujących w ciągłym poczuciu zagrożenia, przekonanych o swoich racjach, mających poczucie misji, pewnych swej przewagi, zaangażowanych ideowo, pielęgnujących troskliwie więzi wewnątrzwspólnotowe, karmiących się poczuciem krzywdy i niesprawiedliwości, mających jasno zarysowany portret wroga, pozwala dość łatwo wypracować sobie spójny i logiczny, a w dodatku bardzo jednoznaczny model postrzegania świata. Uwalnia przy okazji od wysiłku myślenia i bagatelizuje, a nawet odrzuca inne perspektywy patrzenia na rzeczywistość. Mechanizm ten jednak może być niebezpieczny dla wspólnoty — radykalizm bowiem wyzwala radykalizm i prowadzi do eskalacji przemocy. Groźne jest też to, że wiedzę czyni zbędną, zwłaszcza o odmiennościach i różnicach, a więc również edukację ukierunkowaną na coraz lepsze rozumienie innych i siebie. Trafnie diagnozuje to zjawisko Akiwa Eldar, dziennikarz, wykładowca akademicki i pisarz:

My po prostu nie chcemy psuć sobie samopoczucia. Nie lubimy, by męczyć nas faktami, wiedza jest niepotrzebna. [...] Gdzieś w głębi duszy porwat nas projekt osiedli. Dokonała się mentalna aneksja Zachodniego Brzegu. To po prostu nasze. Nie widzimy, że osiedla nas zniszcza ${ }^{12}$.

Radykalizmu nie można lekceważyć — dla życia wspólnotowego nie ma bowiem wielkiego znaczenia jego skala, zwłaszcza jeśli jego oddziaływanie można dostrzec gołym okiem w sferze publicznej. Dlatego Eldar nie wyolbrzymia poziomu społecznego poparcia dla żydowskich radykałów, ale za to mocno eksponuje realny ich wpływ na dyskurs o sprawach istotnych dla izraelskiego społeczeństwa: $W$ dalszym ciagu sa mniejszościa, lecz nadaja ton debacie, maja władze polityczna i ideologiczna. Sa krzykliwi, groźni, ekspansywni ${ }^{13}$.

Milcząca obojętność czy bierna akceptacja tego faktu mogą być jednak bardzo niebezpieczne dla podstaw demokracji, która wyrasta z szacunku dla różnorodności i która prawo do jej wyrażania gwarantuje wszystkim. W imię tego prawa nie może ona przecież akceptować projektów jej zniszczenia. Dlatego Akiwa Elder przestrzega:

Dzisiaj jednak w Izraelu [...] mniejszość dyktuje swoja wolę większości, obojętnej, lekceważacej rzeczywistość, uśpionej wygoda i dostatkiem życia. Jedni żyja dniem dzisiejszym, a dla drugich liczy się przeszłośćc ${ }^{14}$.

\footnotetext{
${ }^{12}$ Ibidem, s. 273.

${ }^{13}$ Ibidem, s. 280.

14 Ibidem, s. 282.
} 


\section{Edukacja antyradykalna}

W kontekście odradzających się i ekspansywnych radykalizmów, zagarniających coraz większe obszary życia społecznego oraz politycznego (również w Polsce), potrzeba zabezpieczenia się przed ich skutkami powinna być jednym $\mathrm{z}$ edukacyjnych priorytetów, zwłaszcza $\mathrm{w}$ szkolnictwie powszechnym, a zarazem integralnym elementem wychowania obywatelskiego. W reporterskiej opowieści Smoleńskiego można odnaleźć kilka inspirujących wskazówek, jak należałoby to praktycznie realizować. Jedną z nich formułuje profesor Daniel Bar-Tal, psycholog społeczny i polityk:

W izraelsko-palestyńskiej rozmowie trzeba wejść w detale, a komu chce się tracić na to czas? [...] Trzeba by byto zastanowić się nad soba, a to niekiedy bardzo boli. Jak opowiadać o wojnach w Gazie, co mówić o ostatnich starciach przy granicy, o demonstracjach i o latawcach podpalajacych izraelskie pola? Po co niuansować, komplikować, jeśli obraz jest w gruncie rzeczy jasny i prosty? ${ }^{15}$.

Pomijając w tej wypowiedzi odniesienia do aktualnej sytuacji polityczno-społecznej w Izraelu, warto zwrócić uwagę przede wszystkim na postulowaną przez izraelskiego intelektualistę potrzebę kształtowania dojrzałej, zdolnej do samokrytyki, autorefleksji nad własną tożsamością, zwłaszcza w jej wymiarze zbiorowym i odniesionym do współczesności. Ta z kolei musi być oparta na analizie faktów i zależności między nimi. Tylko opowieść zniuansowana, utkana z konkretnych sytuacji, zdarzeń i ludzkich losów, pozwala odkryć perspektywę, $\mathrm{z}$ jakiej są one przedstawiane. Dopiero w tak zarysowanych uwarunkowaniach może dość do dialogu (nawet między skonfliktowanymi wspólnotami), który zakłada szacunek dla różnorodności, a w konsekwencji — do rozmaitości postaw, poglądów, racji itp.

Profesor Bar-Tal z niepokojem przygląda się też edukacyjnym mechanizmom ujednoznaczniania rzeczywistości uniemożliwiającym jakiekolwiek uwieloznacznienie obrazu świata:

Analizowaliśmy nasze i palestyńskie podręczniki szkolne. [...] Sa najczęściej etnocentryczne, skupione na własnej krzywdzie, przedstawiaja Innego jako zagrożenie, rzadko ucza empatii. Nie fatszuja historii, a więc nie kłamia, lecz wykrawaja z niej takie kawatki, które pasuja do tezy: jesteśmy wyjątkowi i dlatego musimy liczyć się z agresja ${ }^{16}$.

\footnotetext{
${ }^{15}$ Ibidem, s. 297.

16 Ibidem, s. 296.
} 
Dla polonisty zastanawiającego się nad współczesną polityką historyczną realizowaną przez polskie państwo oraz nad preferowaną koncepcją postrzegania europejskości i pod tym kątem analizującego choćby model polskości wpisany w treści kształcenia oraz obowiązkowe i zalecane teksty literackie na poziomie licealnym, słowa te brzmią dziwnie znajomo i zaskakująco uniwersalnie. Warto jednak pamiętać, że sposób formowania tożsamości narodowej scharakteryzowany przez Bar-Tala na pewno nie zapobiega, a w pewnych uwarunkowaniach może nawet sprzyjać radykalizmowi przybierającemu kształt agresywnego nacjonalizmu, ksenofobii i jawnej wrogości wobec ludzi uznanych za obcych. Dlatego moduł ukazujący zagrożenia wynikające z dominacji tylko jednej, mocno nacechowanej aksjologicznie, etnocentrycznej, idealizującej naród i przeszłość, nieufnej wobec inności, a co za tym idzie, podejrzliwie traktującej wszelkie różnice perspektywy podejmowania namysłu nad polskością, powinien być rdzeniem koncepcji kształcenia troszczącej się o ocalenie prawa do różnorodności.

Rezygnacja z takiego modułu i z edukowania ku różnorodności nie oznacza, iż dojdzie do natychmiastowej ekspansji radykalizmu we wszystkich istotnych obszarach życia społecznego. Bardziej prawdopodobne wydaje się najpierw powstanie obszaru buforowego oddzielającego demokrację liberalną od demokracji kolektywnej. To niezwykle interesujące, ale i bardzo groźne przeobrażenie opisuje cytowany już profesor Bar-Tal. Zwraca on uwagę, że język fanatyzmu zawsze zadaje gwałt wolności i wprowadza najpierw mentalny przymus wszystko zaczyna się od zdyskredytowania inaczej myślących i ograniczenia prawa do wyrażania własnego zdania, jeśli nie jest ono zgodne z dyskursem narzucanym przez radykałów. Jednoznaczność zatem ma na celu zniszczenie różnorodności. Nieprzypadkowo Bar-Tal genezę tego procesu opisuje orwellowskim językiem:

Tak powstaja wymarzone warunki, by myśl zostata zastapiona przez ,,grupomyśl", a więc zaprzeczenie myślenia. Demokracja liberalna, pilnująca wolności jednostki, staje się demokracja kolektywna, a ta zawsze tworzy monopol na kulturę, oświatę, sposób myślenia o państwie, patriotyzm. Można mieć własne zdanie, ale po co, skoro jest ono niestuszne? Albo jesteś z nami, albo przeciwko nam. Z takiej dychotomii nie ma ucieczki, a wychylanie się przeciwko woli większości może być bardzo nieprzyjemnym doświadczeniem ${ }^{17}$.

${ }^{17}$ Ibidem, s. 298. 


\section{Dydaktyka ostrzegawcza}

Czym zatem byłaby dydaktyka ostrzegawcza? Jest to edukacja, która wyrasta $\mathrm{z}$ dwóch równie istotnych źródeł: pogłębionej analizy współczesnych niepokojów, zagrożeń, wyzwań oraz z refleksji nad przeszłością, a zwłaszcza jej najmroczniejszym obliczem ${ }^{18}$. Ostrzega ona przed mechanizmami zniewalania człowieka, narzucaniem mu ideologicznej perspektywy postrzegania świata, upraszczającymi schematami wyjaśniającymi w pozornie prosty sposób bardzo skomplikowane i złożone problemy oraz przed jednoznacznością, która w każdym możliwym obszarze aktywności człowieka ma wyeliminować niejednoznaczność i różnorodność. Przed skutkami tychże działań nie chronią ani demokracja, ani wolność słowa, ani łatwość komunikowania się i przepływu informacji, ani system medialny ${ }^{19}$. Tym zabezpieczeniem przed wspomnianymi zagrożeniami jest indywidualne zaplecze aksjologiczne, którego rdzeń stanowi akceptacja różnorodności. Trafnie ujmuje to Amos Oz, gdy stwierdza:

Humanizm wiąże się z pluralizmem, to znaczy z uznaniem równego dla wszystkich ludzi prawa do tego, by różnić się od siebie, oraz tego, że każda osoba jest całym światem mającym prawo do godnej egzystencji ${ }^{20}$.

Warto zauważyć, że słowa te pochodzą z krótkiej książeczki o znaczącym tytule — Do fanatyków..., w której autor Opowieści o miłości i mroku twierdzi, że jedynym środkiem chroniącym Izraelczyków przed radykalizmem i fanatyzmem jest właśnie tak rozumiany humanizm ${ }^{21}$. Tożsamość, tak istotna dla edukacji kategoria, jest również opisywana przez Oza w tymże duchu — ma ona charakter otwarty, jest dynamiczna i zdolna do redefiniowania się na nowo w wyniku doświadczenia różnorodności:

Tożsamość ma znaczenie tylko i wyłącznie wtedy, gdy drzwi wejściowe są otwarte na oścież. Tylko wtedy, gdy istnieje wolność wyboru. Tylko

${ }^{18} \mathrm{~W}$ tym kontekście należy przywołać choćby książki T. Snydera: Czarna ziemia. Holokaust jako ostrzeżenie. Tłum. B. Pietrzyk. Kraków 2015; T. Snydera: O tyranii. Dwadzieścia lekcji z dwudziestego wieku. Tłum. B. Pietrzyk. Kraków 2017; T. Snydera: Droga do niewolności. Rosja, Europa, Ameryka. Tłum. B. Pietrzyk. Kraków 2019.

19 Zob. T. Garton Ash: Wolne słowo. Dziesięć zasad dla połaczonego świata. Tłum. M. Godyń, F. Godyń. Kraków 2018. Por. S. Vaidhyanathan: Antisocial Media. Jak Facebook oddala nas od siebie i zagraża demokracji. Tłum. W. Mincer, K. Sosnowska. Warszawa 2018.

20 A. Oz: Do fanatyków..., s. 60.

${ }^{21}$ W słowach definiujących jego istotę dosłyszeć można fascynację wieloperspektywicznością świata, jakże bliską choćby innej wielkiej żydowskiej intelektualistce, czyli Hannah Arendt. 
gdy każdy dobrowolnie postanawia utrzymać własną tożsamość i jej nie zmieniać22.

Reporterska opowieść Smoleńskiego, w której poczesne miejsce zajmuje też głos Amosa $\mathrm{Oza}^{23}$, wpisuje się we współczesny wielogłos ostrzegający przed niebezpiecznym urokiem jednoznaczności i pokusą uwiedzenia radykalizmem. Tym istotniejsza w tym kontekście jest rola edukacji humanistycznej ${ }^{24}$. Jej podstawową obligację trafnie wyrażają słowa Gartona Asha zamykające jego znakomite studium poświęcone wartości wolnego słowa:

Jedynie dzięki artykulacji różnic między nami możemy dostrzec wyraźnie, na czym one polegają i dlaczego są takie, a nie inne. [...] Nigdy nie będziemy i nie powinniśmy być jednomyślni. Musimy jednak dążyć do stworzenia uwarunkowań, w których będziemy zgodni co do tego, jak się różnić. W dużej skali, w kosmopolis, to dzieło dopiero się rozpoczyna ${ }^{25}$.

Opis tego, co możemy zyskać dzięki wysłuchaniu wspomnianych ostrzeżeń i akceptacji różnorodności jako immanentnej cechy współczesnego świata, ukazuje Smoleński, przywołując postać rabina Menachema Fromana z Tekoi. Był on wielkim zwolennikiem dialogu ze wszystkimi uczestnikami życia społecznego w Izraelu, w tym także z osadnikami i radykalną żydowską młodzieżą, jak również z radykałami palestyńskimi (przyznawał się do spotkań z przywódcami islamskich fundamentalistów z Hamasu czy Brygad Al-Kassam). Wartością, którą cenił najwyżej i w imię której takie kontakty nawiązywał, był pokój. Nie było

22 A. Oz: Do fanatyków..., s. 87.

${ }^{23}$ Również niezwykle zainteresowanego postrzeganiem świata przez żydowskich osadników, czemu dał wyraz w książce: A. Oz: Na ziemi Izraela. Tłum. M. Czerniew ska. Warszawa 1996.

${ }^{24}$ Tak rozumiana funkcja edukacji szkolnej wpisuje się w oczekiwania, jakie wobec humanistyki formułuje na przykład Ryszard Koziołek. Pisze on o humaniście sygnaliście: „Dostarcza języka i donosi na język. Widzę jego społeczną rolę jako tego, kto donosi na język publiczny, ostrzegając przed jego degradacją, brutalizacją i cyniczną sofistyką. Ale to za mało. Donosiciel języka dostarcza wypowiedzi, które nazwą to, czego nie znam, abym »o zamysłach nieprzyjacielskich mógł wiedzieć« (Linde)”. R. Koziołek: Wiele tytułów. Wołowiec 2019, s. 20. Z tak pojmowaną rolą humanisty wiąże się następująca funkcja szkolnej edukacji humanistycznej: ,,[... kształcenie humanistyczne przygotowuje »sygnalistę«, to jest człowieka zdolnego znaleźć słowa odpowiednie do nazwania tego, co nadchodzi”. Ibidem, s. 22. Koziołek podkreśla w tym kontekście znaczenie literatury pięknej (podobnie jak Łukasz Musiał w książce Do czego używa się literatury?. Kraków 2016), ale przecież opisany wymiar formacyjny w edukacji można urzeczywistniać również za pośrednictwem literatury non-fiction (także tej opisującej inną niż polska rzeczywistość) właśnie po to, by uchwycić procesy i zjawiska, które mogą budzić niepokój. Mimo bowiem iż wydają się dotyczyć kogoś innego, w sprzyjających im warunkach kulturowych, politycznych i społecznych mogą jednak dotyczyć również nas.

${ }^{25}$ T. Garton Ash: Wolne stowo..., s. 613. 
to jednak przekonanie naiwne - by dać temu wyraz, żartobliwie przywoływał akt małżeństwa, stwierdzając, że „małżeństwo to przymierze, a nie narzucanie swego. Pokój jest o wiele bardziej skomplikowany" ${ }^{26}$. Owemu przekonaniu towarzyszył równie silny sprzeciw wobec jakiegokolwiek radykalizmu i traktowania różnorodności jako zagrożenia - dlatego mówił: „Gdy ujarzmiamy, sami jesteśmy ujarzmieni, nienawiść powoduje, że nas nienawidzą"27. Najbardziej intrygujące było jednak jego rozumienie relacji żydowsko-palestyńskich na Zachodnim Brzegu Jordanu, a więc w miejscu, gdzie zaobserwować można niezwykłe natężenie wrogości i przemocy oraz wzajemnej nieufności i obcości, czego symbolem są mury, zasieki, płoty i blokady:

Trudno było zrozumieć rabina Fromana, gdy mówił, że osiedla w Judei i Samarii są jak palce dotykające w przyjaźni i szacunku palców drugiej obcej dłoni. [...] Tam gdzie jest płot, są i związki przerzucone ponad płotem, bo świat jest jednością, a nie zbiorem osobnych bytów ${ }^{28}$.

Zanim ktoś w tym obrazie dopatrzy się utopii i uzna postać rabina z Tekoi za wyjątkowego idealistę i marzyciela, oderwanego od rzeczywistości, głoszącego idee niemożliwe do urzeczywistnienia, powinien także wiedzieć, jak wyglądał jego pogrzeb: „Opłakiwali go zwolennicy, ale też ci, co za życia byli gotowi wyrwać mu język. Żegnały zgodnie rabina lewica i prawica, żegnali osadnicy i wrogowie okupacji, wszyscy pochyleni w żałobnej zadumie"29. Być może zatem warto posłuchać ostrzeżeń mądrych ludzi i chronić siebie oraz innych przed niebezpiecznym urokiem jednoznaczności.

\section{Bibliografia}

Garton Ash T.: Wolne stowo. Dziesięć zasad dla połaczonego świata. Tłum. M. Godyń, F. Godyń. Kraków 2018.

Koziołek R.: Wiele tytułów. Wołowiec 2019.

Musiał Ł.: Do czego używa się literatury?. Kraków 2016.

Oz A.: Do fanatyków. Trzy refleksje. Tłum. L. Kwiatkowski. Poznań 2018.

Oz A.: Na ziemi Izraela. Tłum. M. Czerniewska. Warszawa 1996.

Smoleński P.: Wnuki Jozuego. Wołowiec 2019.

Snyder T.: Czarna ziemia. Holokaust jako ostrzeżenie. Tłum. B. Pietrzyk. Kraków 2015.

\footnotetext{
${ }^{26}$ P. Smoleński: Wnuki Jozuego..., s. 150.

27 Ibidem.

${ }^{28}$ Ibidem.

${ }^{29}$ Ibidem, s. 151.
} 
Snyder T.: Droga do niewolności. Rosja, Europa, Ameryka. Tłum. B. Pietrzyk. Kraków 2019. Snyder T.: O tyranii. Dwadzieścia lekcji z dwudziestego wieku. Tłum. B. Pietrzyk. Kraków 2017. Tłum. W. Mincer, K. Sosnowska. Warszawa 2018.

Vaidhyanathan S.: Antisocial Media. Jak Facebook oddala nas od siebie i zagraża demokracji. 